\title{
骨組の弾塑性増分解析における不平衡力の解消について ON CANCELLATION OF UNBALANCED FORCE VECTOR IN THE ELASTOPLASTIC INCREMENTAL ANALYSIS OF A FRAME
}

\author{
修行 稔 ${ }^{* 1}$
}

Minoru SHUGYO

\begin{abstract}
A procedure to cancel a large unbalanced force vector caused by a sudden fracture of members in the elastoplastic incremental analysis of a frame is presented. By using the procedure, redistribution of the released forces, which are axial force, bending moments, shear forces and axial torsional moment of early fractured brittle member, into the remaining members of the frame can be done, therefore, an accurate restoring force characteristics of the frame including both brittle and ductile members can be obtained. The validity and reliability of the procedure are demonstrated by the numerical experiments on a simple two-bay two-story steel frame.
\end{abstract}

Keywords : Cancellation of unbalanced force vector, Restoring force characteristics, Fibered plastic hinge model 不平衡力解消, 復元力特性, 繊維化塑性関節モデル

\section{1. はじめに}

骨組が外力によって変形していくと, 変形能力の低い脆性的な部 材は比較的早期に壊れ, その部材が負担していた支持力は瞬時に失 われる. このとき, 失われた支持力は骨組が平衡状態になるように 骨組全体の部材に再配分される. 骨組の復元力特性は, この再配分 によって不平衡力を解消しながら求められなければならない，骨組 が弾性状態から崩壊に至るまでの復元力特性は，骨組の性能を把握 する上で最も重要な情報であるが，2015 年版技術基準解説書 ${ }^{1)}$ に は脆性的部材と勒性部材の混在する骨組の復元力特性が模式的に示 してあるものの, それを求める手段については記述がない.

一般に, 骨組の弾塑性大変形領域における力学的挙動の解析では, 弧長法とニュートン・ラフソン法を組み合わせた反復解法で釣り合 い経路を求めることが多い2．しかし，この方法を上記のように部 材が瞬時に破壊する問題に適用するのは難しい. 動的な解析であれ ば，破壊によって瞬間的に生じる不平衡力を慣性力で打ち消寸手法 3) があるが, 準静的な解析には適用できない。準静的な解析では, せん断破壊する $\mathrm{RC}$ 柱について破壊曲面縮小の概念と塑性流れ則で 柱の鉛直変形挙動を定式化した芳村と高稻の研究 ${ }^{4)}$ があり, 堀田と 吉崎はこれを方立て壁を有する $\mathrm{RC}$ 架構の崩壊挙動の評価に適用し て脆性的な壁が架構の崩壊形に及ぼす影響について調べている ${ }^{5)}$ が, 部材の瞬時的な破壊は扱っていない.

本論文は，脆性的部材と勒性部材の混在する骨組について，脆性 的部材がある破壊条件で瞬時に破壊すると仮定できる場合の，不連 続な復元力特性を精度よくかつ簡便に求める方法を提示し, 数值実 験でその有用性を示すものである。

\section{2. 解析法の概要}

解析法の概要の説明を繊維化塑性関節モデル 6),7),8) (以下 FPHM) を基本とした場合について述べる，なお，ほかの解析モデルでも， 要素端の塑性変形増分が後述する(8)式のように弾性変位増分から 完全に分離して求められるモデルであれば，ここで述べる方法がそ のまま適用できる.

FPHM の概念図を Fig.1 に示す. FPHM の挙動に関する仮定は, 対象が $\mathrm{H}$ 形断面材であれば以下の通りである ${ }^{6}$ ．11)部材は薄肉であ り，断面はそり成分を除けば平面を保持する，2）骨組の節点変位は 大きいが部材の弾性ひずみは小さい，3)軸力，二軸曲げモーメント およびそりモーメントによる軸方向応力のみが部材の降伏に寄与寸 る.4)塑性変形成分は軸力, 二軸曲げモーメントおよびそりモーメ ントに対応する 4 成分である.5)局部座屈はない，6)要素内では一

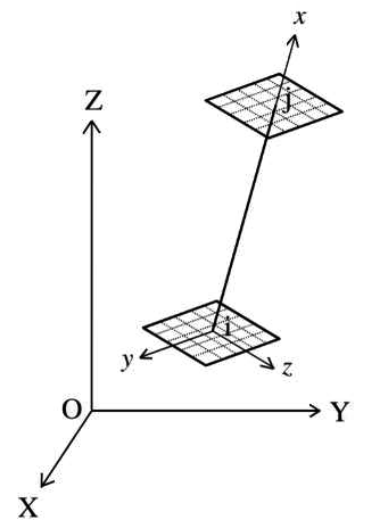

Fig.1 Schematic diagram of Fibered Plastic Hinge Model 
般化塑性ひずみの増分は線形に分布する，7)要素の長さの $1 / 2$ に生 じる塑性変形増分はそれぞれ要素両端 $\mathrm{i}, \mathrm{j}$ の長さ 0 の塑性関節に集 中して生じる.

\section{1 幾何学的非線形剛性行列}

要素の両端を $\mathrm{i}, \mathrm{j}$ とする. i 端の図心を原点として材軸方向に $\mathrm{x}$ 軸，これと右手系をなすように断面主軸方向に $\mathrm{y}, \mathrm{z}$ 軸をとる. 同 様に, $\mathrm{i}$ 端のせん断中心 $\mathrm{S}$ に原点をとり, 材軸方向に $\overline{\mathrm{x}}$ 軸, これと 右手系をなすように断面主軸方向に平行に $\bar{y} ， \bar{z}$ 軸をとる. 仮定 1)〜 2)および modified incremental stiffness methodによって(1)式を 満足する弾性接線剛性行列 $\boldsymbol{K}^{\mathrm{e}}$ が得られる ${ }^{6)}$.

$$
d \boldsymbol{Q}+\boldsymbol{R}=\boldsymbol{K}^{e} d \boldsymbol{q}^{e}
$$

ここに, $\boldsymbol{R}$ は不平衡力, $\boldsymbol{Q}$ と $\boldsymbol{q}^{\boldsymbol{e}}$ はそれぞれ 14 成分からなる要素端力 と要素端弾性変位である. $\boldsymbol{Q}$ と $\boldsymbol{q}^{e}$ の成分は以下のようである.

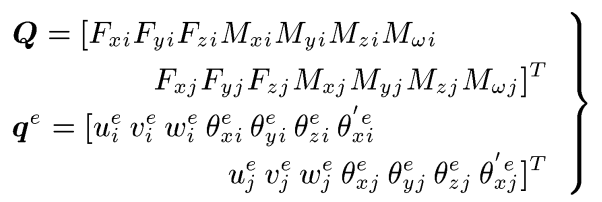

ここに, $F_{k l}$ は $l$ 端の $\mathrm{k}$ 方向の力, $M_{k l}$ は $l$ 端の $\mathrm{k}$ 軸回りのモーメント, $M_{\omega l}$ は $l$ 端のそりモーメントであり, $\boldsymbol{q}^{\boldsymbol{e}}$ の成分は対応する弾性変位で ある。

\section{2 塑性変形増分の評価}

FPHM では, Fig.1のように要素両端を微小な繊維に分割し, 各 時点での䋊維の岡性を断面に関して数值積分して得られる接線係数 行列を利用して塑性変形増分を求めている. $\mathrm{H}$ 形断面材について述 べると, サンブナンのねじりによるせん断応力の影響を考慮しない ので, 繊維の応力増分とひずみ増分の関係は次式で得られる.

$$
d \sigma=E_{t} d \varepsilon
$$

ここに, $\sigma$ は軸力, 曲げモーメントおよびそりモーメントによって 生じる垂直応力, $\varepsilon$ は垂直ひずみ, $E_{t}$ は繊維の一軸応力増分〜ひず み増分関係の比例係数であり, 弾性域ではヤング率 $E$, 降伏後はひ ずみ硬化係数となる.

さて, $\mathrm{H}$ 形断面材の一般化応力 $\boldsymbol{f}$, 一般化ひずみ $\boldsymbol{\delta}$ の成分は次の ようである.

$$
\left.\begin{array}{rl}
\boldsymbol{f} & =\left[\begin{array}{llll}
f_{x} & m_{y} & m_{z} & m_{\omega}
\end{array}\right]^{T} \\
\boldsymbol{\delta} & =\left[\begin{array}{llll}
\varepsilon_{0} & \phi_{y} & \phi_{z} & \phi_{\omega}
\end{array}\right]^{T}
\end{array}\right\}
$$

ここに, $f_{x}$ は軸力, $m_{y}$ と $m_{z}$ は曲げモーメント, $m_{\omega}$ はそりモーメン 卜， $\boldsymbol{\delta}$ の成分はそれぞれに対応する一般化ひずみである. 微小な繊 維に分割した塑性関節部の断面に関し, 繊維の応力と一般化応力の 関係および繊維のひずみと一般化ひずみの関係を用いれば, $\boldsymbol{f}$ の増 分と $\boldsymbol{\delta}$ の増分の間に次のような関係が得られる 6 .

$$
d \boldsymbol{f}=\boldsymbol{t} d \boldsymbol{\delta}
$$

ここに, $\boldsymbol{t}$ は断面に関する接線係数行列である. $\boldsymbol{t}$ は要素の両端断面 についてそれぞれ得られ, それらの成分を利用し変形することによ って(6)式のように一般化塑性ひずみ $\boldsymbol{\delta}^{\boldsymbol{p}}$ の増分と一般化応力増分を 関係づける行列 $\widehat{\boldsymbol{S}}$ が求められる6).

$$
d \boldsymbol{\delta}^{p}=\hat{\boldsymbol{s}} d \boldsymbol{f}
$$

ここで, $\mathrm{H}$ 形断面材の要素両端の塑性関節に生じる塑性変形増分
を次のように定義する.

$$
\left.\begin{array}{rl}
d \boldsymbol{q}_{i}^{p} & =\left[\begin{array}{lllllll}
d u_{i}^{p} & 0 & 0 & 0 & d \theta_{y i}^{p} & d \theta_{z i}^{p} & d \theta_{x i}^{\prime p}
\end{array}\right]^{T} \\
d \boldsymbol{q}_{j}^{p} & =\left[\begin{array}{lllllll}
d u_{j}^{p} & 0 & 0 & 0 & d \theta_{y j}^{p} & d \theta_{z j}^{p} & d \theta_{x j}^{\prime}
\end{array}\right]^{T}
\end{array}\right\}
$$

これらの塑性変形増分は一般化塑性ひずみ増分によって生じるもの である. 要素両端の $\hat{\boldsymbol{s}}$ を利用し, 仮定 6)〜 7)を導入すれば, 要素 両端の塑性変形増分 $d \boldsymbol{q}^{p}$ と要素端力増分 $d \boldsymbol{Q}$ とを関係づける塑性接線 柔性行列 $\boldsymbol{s}^{p}$ を得ることができる ${ }^{6)}$.

$$
d \boldsymbol{q}^{p}=\boldsymbol{s}^{p} d \boldsymbol{Q}
$$

\section{3 弾塑性接線剛性行列}

要素端変位増分 $d \boldsymbol{q}$ が, 弾性変位増分 $d \boldsymbol{q}^{e}$ と塑性関節に生じる塑性 変形増分 $d \boldsymbol{q}^{p}$ の合計として生じると仮定すると，(9)式に示す弾塑性

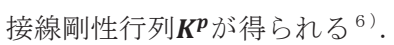

$$
d \boldsymbol{Q}+\boldsymbol{R}=\left[\boldsymbol{I}+\boldsymbol{K}^{e} \boldsymbol{s}^{p}\right]^{-1} \boldsymbol{K}^{e} d \boldsymbol{q} \equiv \boldsymbol{K}^{p} d \boldsymbol{q}
$$

ここに, $\boldsymbol{Q}$ と $\boldsymbol{q}$ はそれぞれ 14 成分からなる要素端力と要素端変位, $\boldsymbol{R}$ は不平衡力, $\boldsymbol{I}$ は単位行列, $\boldsymbol{K}^{e}$ は弹性接線剛性行列, $\boldsymbol{K}^{p}$ は弾塑性 接線剛性行列である. $\boldsymbol{q}$ は弾性成分 $\boldsymbol{q}^{e}$ と塑性成分 $\boldsymbol{q}^{p}$ の和であり, 増 分で表すと(10)式となる.

$$
d \boldsymbol{q}=d \boldsymbol{q}^{e}+d \boldsymbol{q}^{p}
$$

ところで, 骨組の中のある部材が瞬時に壊れると, その他の部材 の一般化応力も瞬時に大きく変動する. (5)式中の $\boldsymbol{t}$ を定める計算の 手順はこの大きな変動に耐えるものである必要がある. FPHM では 塑性関節部断面の微小な䋊維（H 形断面材では 246）すべてについ て弾塑性繰返し挙動を個別に管理し, $\boldsymbol{t}$ が 4 次の正方行列であるの で 4 変数のニュートン・ラフソン法を適用して䋊維を一本ずつ降伏 させ, 繊維に除荷が生じたら弾性に変えて再計算しつつ変動後の一 般化応力の状態に収束させている. これによって, 一般化応力の大 きな変動に対して解析の安定性が保たれているものと思われる.

\section{3. 不平衡力の解消方法}

不平衡力は現ステップまでの外力増分の積算值から現時点での内 力を差し引いたものであるから, 不平衡力を精度よく解消寸るため にはこの内力を正確に評価する必要がある. FPHMのような塑性関 節モデルで骨組を解析した場合, 部材の塑性変形は部材端の長さ 0 の塑性関節に集中して生じてそのエネルギーは熱として散逸し, 弾 塑性大変形状態の骨組には現時点での外力に対応する弾性ひずみエ ネルギーのみが存在していることになる (Fig.2 参照).

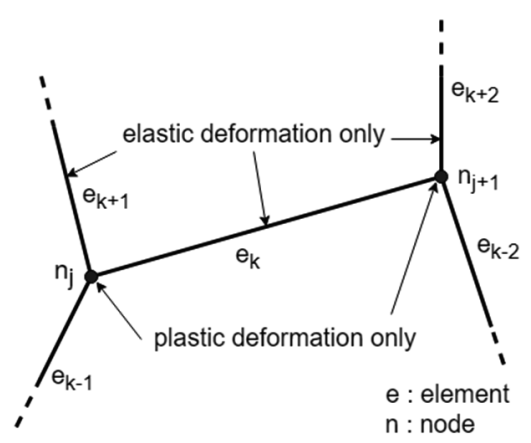

Fig.2 A typical result of the frame analysis using FPHM 
本研究ではこの点に着目し, 骨組の各要素の現時点の弾性ひずみ エネルギーの勾配として要素の内力を評価し, これを座標変換して 骨組全体で総和をとり骨組の内力とする。要素の弾性ひずみエネル ギーは幾何学的非線形性を考慮すると要素両端の弾性変位の関数と なるため, 解析の各ステップにおいて各要素の要素座標軸の方向余 弦を評価し直すとともに剛体変位成分を除いた真の要素端全変位成 分 $\boldsymbol{q}$ 求め ${ }^{9)}$, その全変位成分から $(8)$ 式の $d \boldsymbol{q}^{p}$ を積算した塑性変形成 分 $\boldsymbol{q}^{p}$ 差し引いて弾性変位成分 $\boldsymbol{q}^{e}$ を確定し, これを内力の計算に用 いる. すなわち, Fig.2 中の要素番号 $\mathrm{k}$ の要素の現ステップにおけ る真の要素端全変位を $\boldsymbol{q}_{k}$, 現ステップまでの $d \boldsymbol{q}_{k}^{p}$ を積算した要素端 塑性変形を $\boldsymbol{q}_{k}^{p}$ とすると, 現ステップにおける要素端弾性変位 $\boldsymbol{q}_{k}^{e}$ が次 式で得られる。

$$
\boldsymbol{q}_{k}^{e}=\boldsymbol{q}_{k}-\boldsymbol{q}_{k}^{p}
$$

ここに，下添字 $\mathrm{k}$ は要素番号である．この糔を用いて弾性ひずみエ ネルギーを評価して勾配を求めれば現ステップにおける要素番号 $\mathrm{k}$ の要素の内力が得られる. この内力は要素座標系でのものなので全 体座標系に座標変換し, すべての要素についてそれぞれが関与する 節点に加え込めば，骨組の全節点の全体座標系における内力が求ま る.この内力を用いて不平衡力を解消する方法を解消方法 1 とする.

比較のため, 一般に行われているように, 各ステップで増分解析 の結果として得られる骨組の全体座標系での節点変位増分の值から 要素番号 $\mathrm{k}$ の要素の両端の節点の変位増分を要素座標系に変換して 要素両端の変位増分 $d \boldsymbol{q}_{k}$ を求め, これに要素のそのステップでの弾 塑性接線剛性行列を乗じて得られる内力増分 $d \boldsymbol{Q}_{k}$ を順次積算するこ とによって現ステップにおける要素番号 $\mathrm{k} の$ 要素の内力を得る方法 も試みる。骨組の全節点の全体座標系における内力の求め方は解消 方法 1 と同じである。これを解消方法 2 とする.

増分解析法としてはRamm の変位制御型荷重増分法 10)を用いる. 以下はすべて全体座標系での記述である。骨組全体の接線剛性行列 をKで表すと，固定点を除いた剛性方程式は，

$$
\left[\begin{array}{ll}
\boldsymbol{K}_{11} & \boldsymbol{K}_{12} \\
\boldsymbol{K}_{21} & K_{22}
\end{array}\right]\left\{\begin{array}{l}
\Delta \boldsymbol{u}_{1} \\
\Delta u_{2}
\end{array}\right\}=\Delta \lambda\left\{\begin{array}{l}
\boldsymbol{P}_{1} \\
P_{2}
\end{array}\right\}+\left\{\begin{array}{l}
\boldsymbol{L}_{1} \\
L_{2}
\end{array}\right\}
$$

のように書ける.ここに, $\Delta \boldsymbol{u}=\left\{\Delta \boldsymbol{u}_{1} \Delta u_{2}\right\}$ は変位増分であり, $\Delta u_{2}$ が 1 自由度の制御用変位増分, $\Delta \boldsymbol{u}_{1}$ は制御用変位増分以外の変位増分で

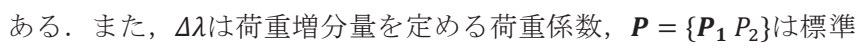
荷重, $\boldsymbol{L}=\left\{\boldsymbol{L}_{1} L_{2}\right\}$ は全体座標系における不平衡力である. $\boldsymbol{P}$ による変 位増分を $\Delta \boldsymbol{u}^{\mathrm{I}}, \boldsymbol{L}$ による変位増分を $\Delta \boldsymbol{u}^{\mathrm{II}}$ で表すと次式が得られる。

$$
\Delta \boldsymbol{u}^{\mathrm{I}}=\boldsymbol{K}^{-1} \boldsymbol{P}, \quad \Delta \boldsymbol{u}^{\mathrm{I}}=\boldsymbol{K}^{-1} \boldsymbol{L}
$$

$\Delta \boldsymbol{u}^{\mathrm{I}}$ の $\Delta \lambda$ 倍と $\Delta \boldsymbol{u}^{\mathrm{II}}$ の合計が変位増分 $\Delta u$ であるから,

$$
\Delta \boldsymbol{u}=\Delta \lambda \Delta \boldsymbol{u}^{\mathrm{I}}+\Delta \boldsymbol{u}^{\mathrm{II}}
$$

となる，ところが， $\Delta \boldsymbol{u}$ の成分である $\Delta u_{2}$ に関しては， $\bar{u}_{2}$ をちえられ た制御用変位増分として,

$$
\Delta u_{2}=\Delta \lambda \Delta u_{2}^{\mathrm{I}}+\Delta u_{2}^{\mathrm{II}}=\bar{u}_{2}
$$

という条件があるので，次式によって $\Delta \lambda$ を決定できる.

$$
\Delta \lambda=\left(\bar{u}_{2}-\Delta u_{2}^{\mathrm{II}}\right) / \Delta u_{2}^{\mathrm{I}}
$$

以上により，1 ステップで 1 回の不平衡力の修正が行われ，変位増 分を小さくとれば反復修正を行うことなく精度の良い安定した解析 が可能となる。一般の剛接骨組であれば，変位増分を初期降伏時の
変位の $1 / 50$ ～1/100 程度にとれば収束した解が得られることを確認 している.

\section{4. 不平衡力解消方法の妥当性の検証}

前章で述べた不平衡力解消方法の妥当性を調べるため, 鈴木らが 実験を行い 11), 藤本と緑川が精密な数值解析を実施した 12 )引張りブ レースを有する 1 層 1 スパン立体骨組の繰返し弾塑性挙動を解析し て実験結果と比較する。

\section{1 実験骨組の概要}

文献 11 の $\mathrm{A} 2$ 試験体を解析の対象とする. 平行する 2 つの門形 一メンと，それに直交する 2 つのブレース付き骨組からなる 4 本柱 の立体骨組である. Fig. 3 に骨組の形状と寸法を示す.柱の長さ 1800 はベースプレート下端からはりの図心までの距離である ${ }^{11) .}$

使用材料は，柱とはりがすべて SS41 の H-100×100×6×8，ブ レースは $22 \phi$ の丸鋼である. 材料定数は以下の通りである. H 形鋼 の降伏応力 $\sigma_{y}=284.2 \mathrm{~N} / \mathrm{mm}^{2}$, ヤング率 $E=214,600 \mathrm{~N} / \mathrm{mm}^{2}$, 丸鋼は $\sigma_{y}=253.8 \mathrm{~N} / \mathrm{mm}^{2}, \quad E=217,600 \mathrm{~N} / \mathrm{mm}^{2}$.

\section{2 載荷方法と水平力の規準値}

各柱頭への柱の降伏軸力 $P_{y}$ の 0.2 倍の鉛直力 $P_{0}$ の下向き載荷の後, Fig.3(c)のように $\mathrm{X}$ 形に各柱頭を繋ぐ $\mathrm{H}$ 形鋼製の水平ブレースの交 点に, 図に示寸方向に水平力 $H$ が繰返し載荷されている. 載荷方向 と X 軸とのなす角 $\theta_{1}$ は $54.2^{\circ}$ である。

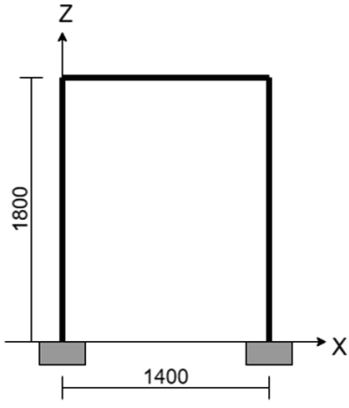

(a) rigid frame

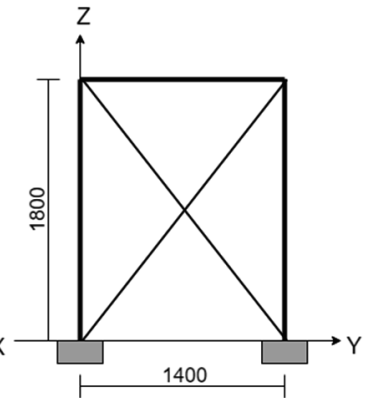

(b) braced frame

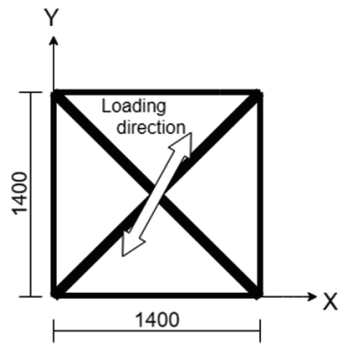

(c) plan view

Fig. 3 Test specimen ${ }^{11}$

解析結果を実験結果と比較するためには, 解析結果の水平力 $H$ を 文献 11 で用いられた規準值 $H_{p c}$ で無次元化し, 載荷点の水平変位の 載荷方向成分の層間変形角を求める必要がある. $H_{p c}$ は以下のように 定義されている. まず $\mathrm{X}$ 方向の柱せん断力の規淮值 $Q_{p x}$ を定める. $Q_{p x}$ は 4 本の柱の上下端に塑性ヒンジが生じるときのせん断力であ り，文献 11 の式を簡素化すると次式で得られる.

$$
Q_{p x}=M_{y} \times 1.18 \times\left(1-P_{0} / P_{y}\right) /\left(h^{\prime} / 2\right) \times 4
$$

ここに, $M_{y}$ は柱強軸回りの降伏曲げモーメント， $h^{\prime}$ ははり下端から 
ベースプレート上端までの柱実長である. 水平力の規準值 $H_{p c}$ として は, $H$ の 方向成分が $Q_{p x}$ となるときの值を用いている.

$$
H_{p c}=Q_{p x} / \cos \theta_{1}
$$

載荷点の水平変位の載荷方向成分の層間変形角 $\alpha$ は, 載荷点の $\mathrm{X}$ 方 向変位を $u, \mathrm{Y}$ 方向変位をvとすると次式で得られる.

$$
\alpha=\left(u \cos \theta_{1}+v \sin \theta_{1}\right) / 1800
$$

載荷の制御は(19)式の $\alpha$ を用いてなされている.

\section{3 解析で用いる引張りブレース要素の特性}

解析で必要となる引張りブレースの力学的特性の評価には, 筆者 が定式化した引張りブレース要素 13)を用いる. Fig.4に, Fig.3 の骨 組のブレース材（直径 $d=22 \mathrm{~mm}$, 長さ $l=2,280 \mathrm{~mm}$ の丸鋼）の繰返 し挙動の一例を示す. 縦軸が軸荷重, 横軸が伸びである. 丸鋼の一 端を固定し他端に軸力を繰返し載荷している。

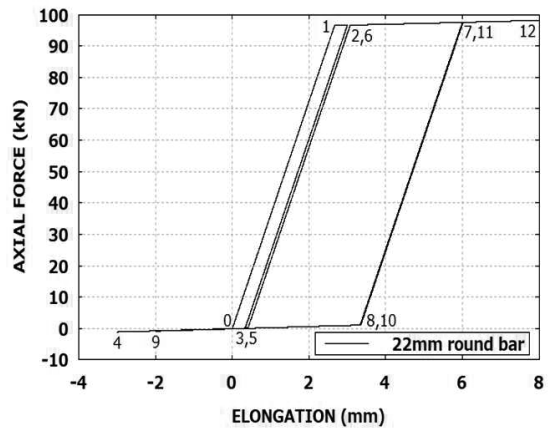

Fig.4 Axial force-elongation relationship of a brace

材料定数は $\sigma_{y}=253.8 \mathrm{~N} / \mathrm{mm}^{2}, \quad E=217,600 \mathrm{~N} / \mathrm{mm}^{2}$ であり, 軸方向 塑性接線柔性 $C_{1}$ は $C_{1}=0.0055 \mathrm{~mm} / \mathrm{N}$ と仮定する。この $C_{1}$ の值は, 断 面積 $A=380 \mathrm{~mm}^{2}$ と $E$ および $l$ から軸剛性 $E A / l$ の $1 / 200$ の逆数とし
て求めたものである。載荷は自由端の軸方向変位で制御し， $3,-3$, 6, - - 2, $8(\mathrm{~mm})$ を除荷点と寸る繰返し載荷とした. Fig.4 中の数字 は経路の順序を示寸. 経路番号の 2 と 6 および 3 と 5 の点は本来一 致すべきであるが少しずれている。この要素は除荷や再降伏を軸力 のみで判断し，除荷点の伸び量を管理していないので，増分解析の きざみ值が大きいと Fig.4 より大きなずれも生じ得る。また，圧縮 時の抵抗力も無視している。 この引張りブレース要素を用いるとき は，これらの点に留意する必要がある.

\section{4 実験結果と解析結果の比較と考察}

解析は FPHM の自動再分割機能 8)を使って柱とはりは部材の長 さの $1 / 10,1 / 2$ ，および $9 / 10$ の点に節点を設けて 1 部材を 4 要素で 近似し，ブレースは上に述べた引張りブレース要素でモデル化して 行った，以下，鈴木らの実験結果を○で，解析結果を実線で示す.

Fig. 5 と Fig.6は，それぞれ $H / H_{p c} \sim \alpha$ 関係および $H / H_{p c} \sim \beta$ 関係 の比較図である。ここに, $\alpha$ は前述の層間変形角, $\beta$ は水平力載荷 点（各柱頭を繋ぐ水平ブレースの交点）の㸚じれ角である．増分解 析に際しては, 水平力載荷点の載荷方向変位を制御変位として, 変 位増分を層間変形角で約 $0.00001 \mathrm{rad}$ にあたる $0.02 \mathrm{~mm}$ とした。こ の変位増分を $0.01 \mathrm{~mm}$ としても結果にはほとんじ影響しない.

これらの図から, 水平力と層間変形角の関係，水平力とねじれ角 の関係のいずれも, 解消方法 1 の結果 (Fig.5(a) と Fig.6(a)) が実験 值に最も近いことがわかる. 負方向載荷時に水平力をやや小さめに 評価し, 解析で用いた引張りブレース要素が圧縮側の抵抗力を考慮 していないために除荷から逆負荷にかけて実験とのかなりの差が生 じるが，これらの点を除けば解析結果と実験結果は概ね対応してい ると言える. 解消方法 2 (Fig.5(b) と Fig.6(b)) では, 水平力が繰返 しにともなって低下してしまい, ねじれ角も実験值から離れる傾向

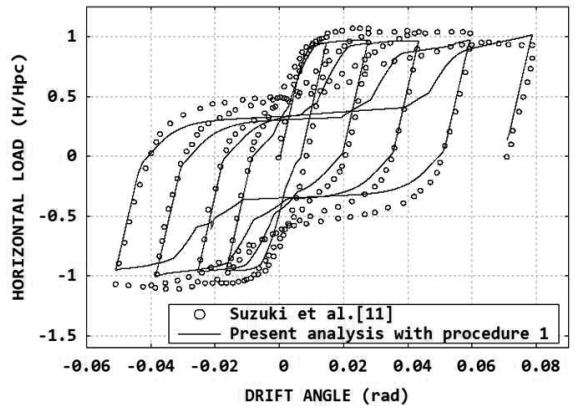

(a) Unbalanced-force cancellation proc. 1

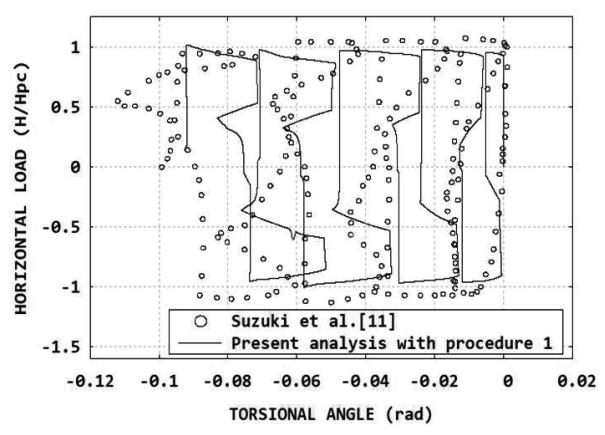

(a) Unbalanced-force cancellation proc. 1

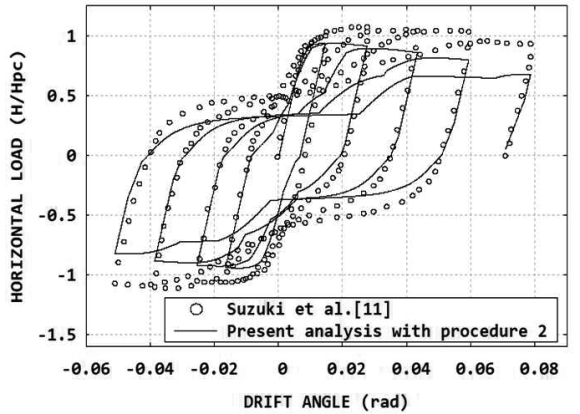

(b) Unbalanced-force cancellation proc. 2

Fig.5 Comparison of $\mathrm{H} / \mathrm{H}_{p c}-\alpha$ relationships

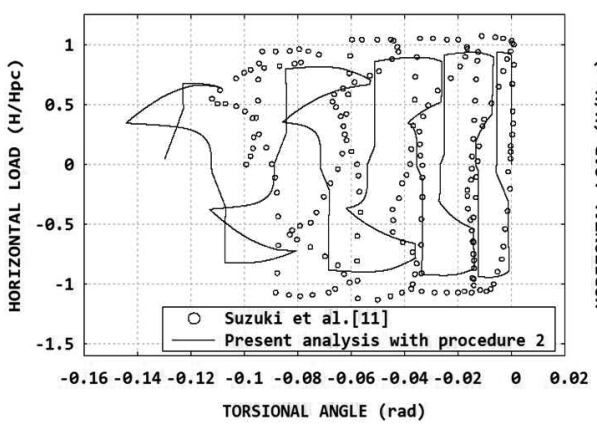

(b) Unbalanced-force cancellation proc. 2

Fig.6 Comparison of $H / H_{p c}-\beta$ relationships

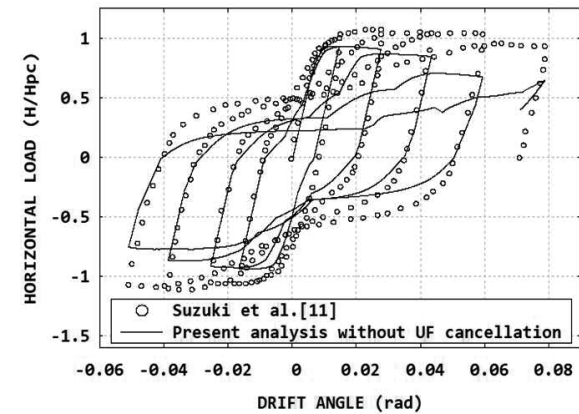

(c) Without unbalanced-force cancellation

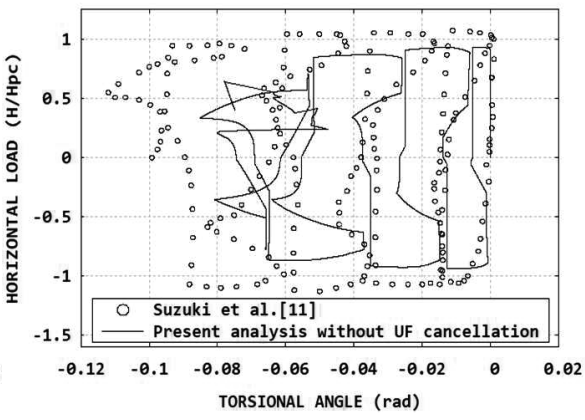

(c) Without unbalanced-force cancellation 
が強くなる. Fig.5(c) と Fig.6(c)は不平衡力を解消しないときの結果 であるが, 解消方法 2 の持つ傾向がより強くなり, ねじれ角は大き く乱れる. 解消方法 1 と解消方法 2 の結果の差の原因は, FPHM そ のものが増分解析の中で骨組の変形の進行に合わせて各要素の要素 座標軸の再設定を繰り返していることもあって特定が難しい。

藤本と緑川 ${ }^{12}$ ) は, 引張りブレースを有する 1 層 1 スパン立体骨組 の動的弾塑性応答の研究に際して, 復元力特性を得るための骨組解 析モデルの妥当性を示すことを目的として, Fig.3 に示す骨組を解 析して実験值と比較している. この解析モデルは, 床板とはりを剛 体とみなし, 柱 4 本をそれぞれ材軸方向に 20 分割して, 柱たわみ 曲線の考えに基づく数值積分法で柱自体の釣合いを常に監視しつつ 解析を進める精密なモデルである. Fig.7 に, Fig.5(a)と Fig.6(a)に 藤本と緑川の解析結果を重衫て描いたものを示す.
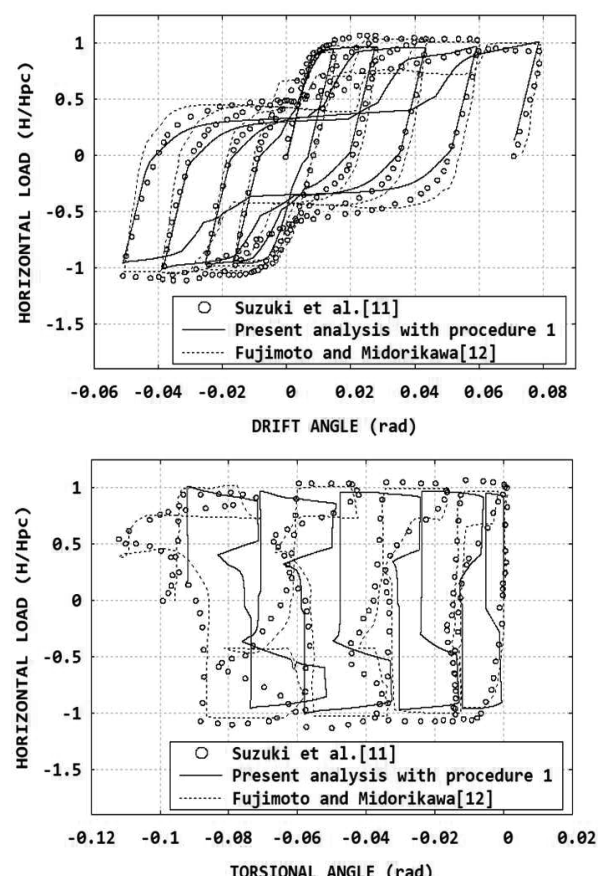

Fig.7 Comparison of $H / H_{p c}-\alpha$ and $H / H_{p c}-\beta$ relationships

実験值との相違という視点で見れば, 水平力〜層間変形角関係に ついては本解法と藤本・緑川の結果はほぼ同程度であると言えるが, 水平力〜㸚じれ角関係については, 藤本と緑川の結果は実験值をほ ぼそのまま再現しているのに対し, 本解法の結果は繰返しねじれ挙 動の傾向はよく表現しているものの, 載荷当初から実験值との差が 見られる.この点は本解法の限界である可能性も含めて今後の検討 課題としたい.

\section{5 平面解析における解消方法の違いによる結果の比較例}

前節の例題は, ブレース付き立体骨組の弾塑性放じれを伴う 3 次 元挙動であったので, 平面解析での不平衡力解消方法の違いによる 結果の差を調べるため, 解析のみの比較になるが, Fig.3 の骨組の X 方向変位をすべての節点で拘束し，Y方向（すなわちブレース骨組 の構面)にのみ繰返し載荷を行って結果を比較した.解析に際して, $P \Delta$ 効果がより大きくなるように各柱頭への初期鉛直力を柱の降伏 軸力 $P_{y}$ の 0.4 倍とした. 載荷は 4.2 節で定義したvで制御し, 変位 増分を $0.01 \mathrm{~mm}$, 除荷点の変位を $50,-50,100,-100,150,-120$
( $\mathrm{mm})$ に設定して行った. Fig. 8 が, 解消方法 1 , 解消方法 2 およ び不平衡力の解消なしの場合の結果の比較図である. 縦軸は水平力 $H$ を 4.4 節と同じく $H_{p c}$ の值で，横軸はvを $\left.1800 （ \mathrm{~mm}\right)$ でそれぞれ 無次元化して描いている.

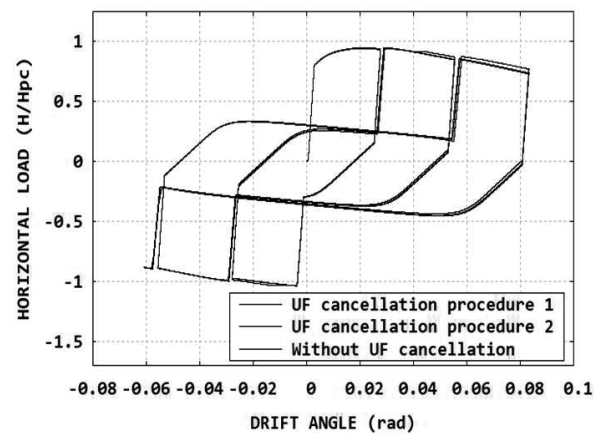

Fig.8 Comparison of $H / H_{p c}-\alpha$ relationships under cyclic loading in $\mathrm{Y}$-direction

図から明らかなように, 解消方法 1 の結果がわずかに異なるが, 3 者の結果はほぼ一致している。これは基本となる解法（FPHM） そのものが時々刻々と変わる各要素の方向余弦をかなり厳密に評価 し直し, 剛体変位を除去していることから不平衡力が小さいためで あると考えられる，この 1 例から確定的なことは言えないが，平面 解析では必ずしも解消方法 1 に拘る必要はないと思われる.

\section{5.はりが脆性的に壊れる骨組の数值実験}

本章以降, 解消方法 1 で不平衡力を解消しつつ変位制御型荷重増 分法で解く解法を本解法と呼ぶ. 本章では, 水平力の増分載荷で一 部のはりが早期に瞬時に破壊する骨組の復元力特性を, 実際に行わ れていると思われる次の 5 種類の解析法を適用して数值実験で求め, 各解析法がもたらす結果の差を明らかにする．（i 破壊を無視する， （ii）破壞した部材を骨組から除く（以後「破壊を考慮する」と表記） が，不平衡力を解消しない，（iii）破壞を考慮し本解法で解く, (iv) 破壊を考慮し不平衡力を解消しつつ, 変位制御型ではない通常の荷 重増分法で解く, ( v ) 破壊する部材を当初から除く.上記( iv)以外の 増分解析はすべて 3 章で述べた変位制御型荷重増分法で行う。

\section{1 数值実験用 2 層 2 スパン骨組}

Fig. 9 が数值実験用の 2 層 2 スパンの平面骨組である. 裸の数字 が節点番号, 丸付き数字が部材番号である. 各部材の断面寸法と材 料定数は以下の通りである.

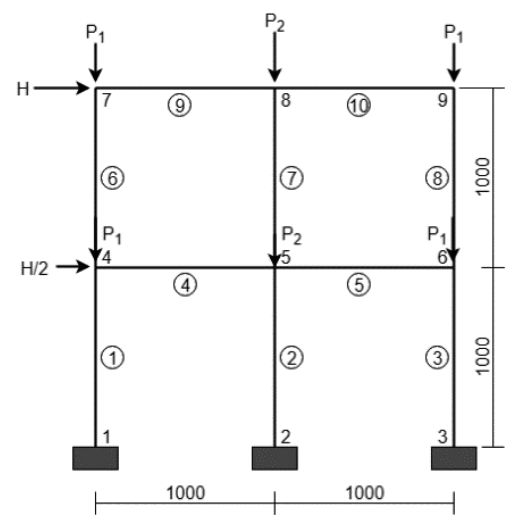

Fig.9 Two-bay two-story plane frame 
部材 (4),(5),(9),(10については $\mathrm{H}-100 \times 100 \times 6 \times 8 ， \sigma_{y}=150 \mathrm{~N} / \mathrm{mm}^{2}$, $E=200,000 \mathrm{~N} / \mathrm{mm}^{2}$, 降伏後のひずみ硬化係数 $E_{t}=E / 100$. 上記以外 の部材は $\mathrm{H}-100 \times 100 \times 6 \times 8, \sigma_{y}=300 \mathrm{~N} / \mathrm{mm}^{2}, E=200,000 \mathrm{~N} / \mathrm{mm}^{2}$, $E_{t}=E / 100$ とする.

すなわち，はりの強度を低くして早期に降伏するように設定して いる. 初期鉛直力は 1 階の (1) ( (3)の柱にそれぞれの柱の降伏軸力 $P_{y}$ の 0.2 倍, (2)の柱に同じく 0.4 倍を載荷する. いずれの柱も断面積 $A=2,100 \mathrm{~mm}^{2}$ なので, Fig. 9 から $P_{1}=2,100 \times 300 \times 0.1=63 \mathrm{kN}, P_{2}=$ $2,100 \times 300 \times 0.2=126 \mathrm{kN}$ となる. 一方, 水平力 $H$ は Fig. 9 のように 2 个所に比例的に漸増載荷する.

解析に際しては前章と同じく 1 部材を 4 要素で近似する. 補正モ デル 7), 8)を用いれば 1 部材 1 要素近似でも実用的な精度が期待でき るが,ここでは精度を特に重視して 1 部材 4 要素近似とした.また, 節点 7 の水平荷重 $H$ の方向の変位 $u_{7}$ を制御変位として, 変位増分を $0.05 \mathrm{~mm}$ とした。 なお, 通常の荷重増分法のときはHの増分を $20 \mathrm{~N}$ とした.

\section{2 部材の破壊条件の設定}

一般に, 部材の破壊条件は部材に生じる軸力やせん断力によって 定義されるが, 本研究の目的は不平衡力の扱いの違いによる骨組の 復元力特性の性状の差を調べることであり, FPHM では(8)式中の $\boldsymbol{s}^{p}$ を求める過程で要素端塑性関節部の繊維のひずみが得られるので, 簡明に(20)式を破壊条件式とする.

$$
|\varepsilon|_{\max }=\eta \varepsilon_{y}
$$

ここに, $|\varepsilon|_{\max }$ は要素の纎維の垂直ひずみ量の最大值， $\varepsilon_{y}$ は同じく 初期降伏ひずみ, $\eta$ は破壊判定值である. 本研究では $\eta=3$ とする. 破壊条件を満たした部材は瞬時にすべての支持力を失うと仮定し, 剛性を0 とおいて実質的に骨組から取り除く.

\section{3 数值実験 1 の解析と考察}

数值実験としては $(20)$ 式の破壊条件式をすべての部材に適用する のが自然であるが，Fig.9 の骨組の場合この設定で解析を行うとま ず部材(4)と(5)がほぼ同時に壊れ, さらに水平荷重を増やしていくと 部材(9)と(10)が同様にほぼ同時に壊れるため, 部材が順次壊れていく ときの復元力の変化を示す例題として必ずしも適切ではない. そこ で, 数值実験 1 では, 破壊が部材(4)にのみおこると仮定する.

Fig. 10 は $H$ と $u_{7}$ の関係の比較, Fig. 11 は $H$ と節点 5 の鉛直方向 (上 向きが正）の変位 $w_{5}$ との関係の比較である. 図中の UF は Unbalanced Force の略である. 実線は破壊を無視したとき, 破線 は破壊を考慮して不平衡力を解消しないとき，点線は破壊を考慮し た本解法, 1 点鎖線は破壞を考慮し不平衡力を解消しつつ通常の荷 重増分法で解いたとき, 2 点鎖線は当初から部材(4)を除いた骨組の 結果である。

まず本解法の結果（点線）に注目すると, 図中の a 点で部材(4)が 壊れ, 2 ステップ程度で復元力が一気に低下して $\mathrm{b}$ 点に到達する. その後は当初から部材(4)のない骨組 (2 点鎖線) とほぼ同じ挙動を 示す．この傾向は文献 1 の模式図と定性的に一致している. 1 点鎖 線の挙動から, 不平衡力を解消しても通常の荷重増分法では復元力 の低下は検出できず，本来低下が生じる範囲では完全塑性形になる ことがわかる、a 点ではりが破壊すると支持力の一部が失われ, 骨 組の剛性も低下寸るため, 微小な荷重増分でも変形が急速に進行す

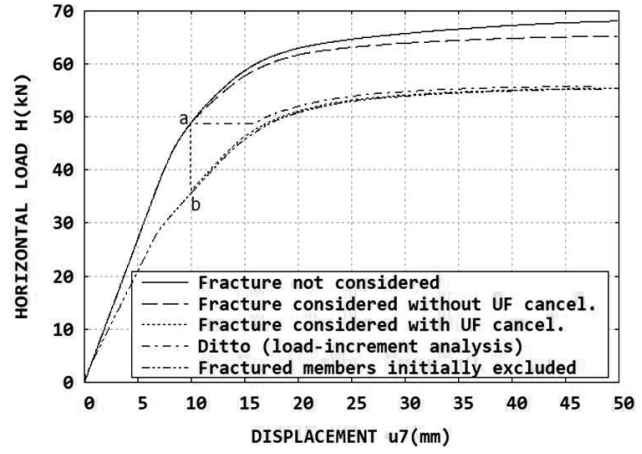

Fig.10 Comparison of $\mathrm{H}-u_{7}$ relationships

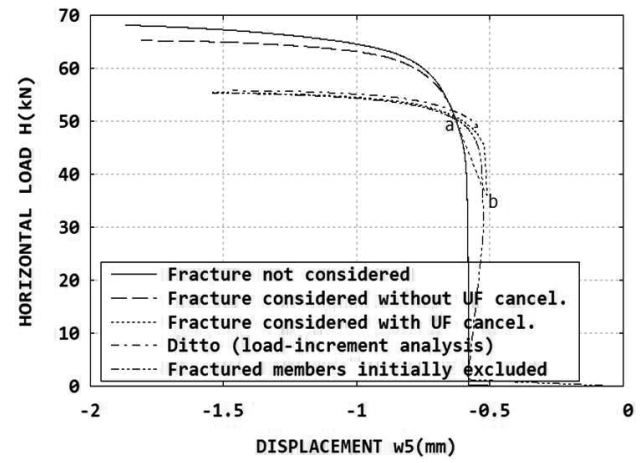

Fig.11 Comparison of $\mathrm{H}$-w5 relationships

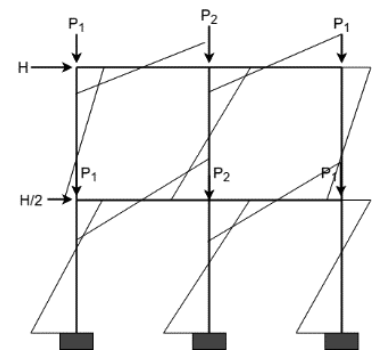

(a) point a

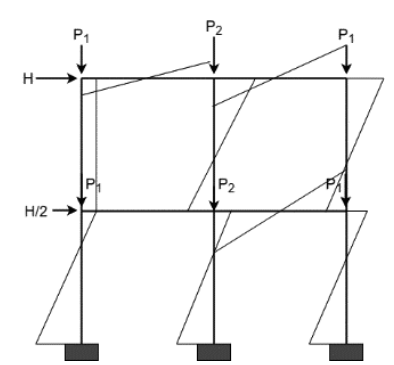

(b) point b
Fig.12 Bending moment diagram

る. $\mathrm{a}$ 点の変位 $u_{7}$ の值は $9.92 \mathrm{~mm}$ であるが，次のステップでは $14.1 \mathrm{~mm}$ になる.

破壊を無視したとき（実線）と破壊を考慮して不平衡力を解消し ないとき（破線）の結果には大きな違いはなく，載荷の途中で破壊 した部材を取り除くだけで解析を進めると, 骨組の保有水平耐力を 大きく評価してしまう危険があると言える.

Fig.12 は Fig.10 と Fig.11 中の a 点と b 点における骨組の曲げモ 一メント分布図である。いずれも本解法の結果である。図からは消 去していないが, Fig.12のb 点の骨組には部材(4)のはりは存在しな い. $\mathrm{a}$ 点では水平力を受ける 2 層 2 スパン骨組の一般的な曲げモー メント分布であるが, $\mathrm{b}$ 点では部材(4)がないため節点 4 に載荷され るH/2 は部材(1) と (6)の柱で支える形になっていることがわかる．当 初から部材(4)を除いた骨組の b 点における曲げモーメント分布は, Fig.12のb 点の分布とほとんど同じになる.

\section{4 数值実験 2 の解析と考察}

数值実験 2 では, 破壊が部材(4)に加えて部材(10にもおこると仮定 する．理由は前述の通りである.

Fig. 13 は $H$ と $u_{7}$ の関係の比較，Fig. 14 は $H$ と節点 8 の鉛直方向の 
変位 $w_{8}$ との関係の比較である. 図中の線種の意味は数值実験 1 と同 じである.

本解法の結果 (点線) に注目すると, 図中の $\mathrm{a}$ 点で部材(4)が壊れ, c 点で部材(10が壞れたあと, 当初から部材 (4)と (10)のない骨組 (2 点鎖 線）とほぼ同じ挙動を示す. 1 点鎖線の挙動から, 不平衡力を解消 しても通常の荷重増分法では復元力の大幅な低下を検出できないこ とがわかる.また，破壞を無視したとき（実線）と破壊を考慮して 不平衡力を解消しないとき(破線)の結果には大きな差は見られず, 数值実験 1 と同じことが言える.

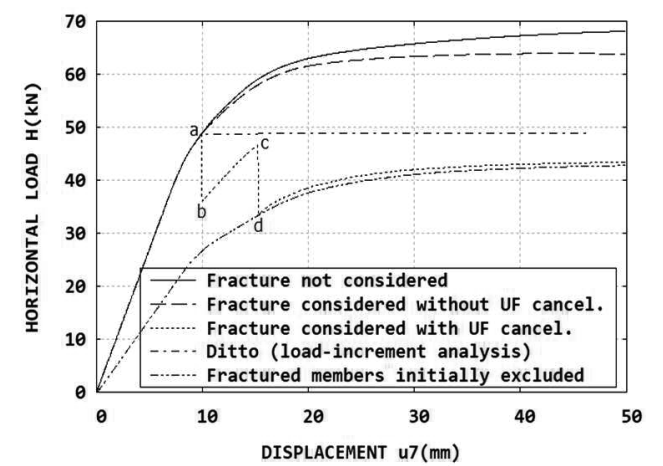

Fig. 13 Comparison of $\mathrm{H}-u_{7}$ relationships

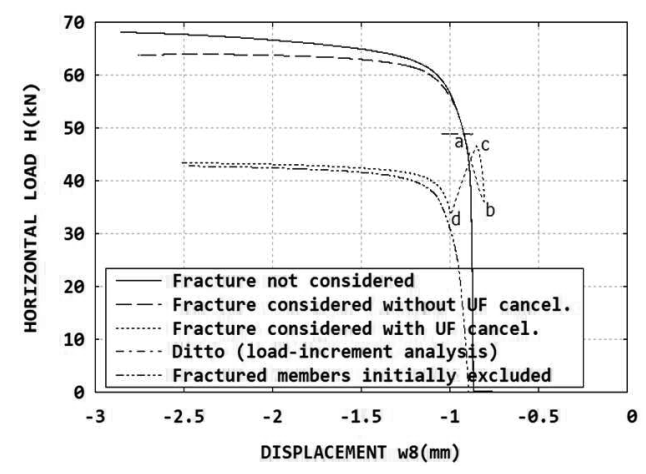

Fig. 14 Comparison of $H$-w8 relationships

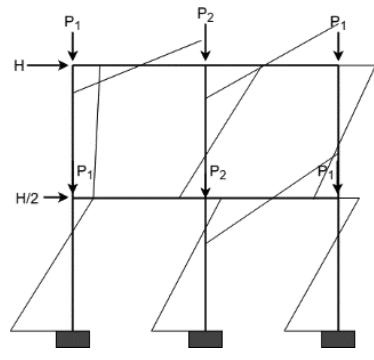

(a) point c

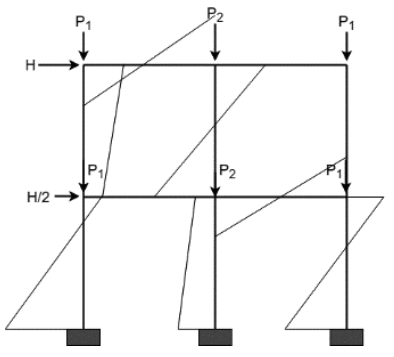

(b) point d
Fig.15 Bending moment diagram

Fig.15 は Fig.13 と Fig.14 中の c 点とd 点における骨組の曲げモ ーメント分布図である。、ずれも本解法の結果である. 図からは消 去していないが, Fig.15の c 点の骨組には部材(4)のはりは存在せず, 同じく d 点の骨組には部材(4)と(10)はりは存在しない. c 点の曲げ モーメント分布は Fig.12の b 点と同じパターンで水平力の増加分だ け值が大きくなる. d 点では部材(10のはりが壊れているので, 部材 (8)の柱には節点 9 に載荷された $P_{1}$ と骨組の変形に起因する付加曲げ モーメントのみが生じる（值が小さいので図には描いていない）。当
初から部材 (4)と(10を除いた骨組の d 点における曲げモーメント分布 は, Fig.15のd点の分布とほぼ一致する.

なお, 以上の数值実験は Fig.9 に示寸平面骨組について行われて いるため，4.5 節で述べたように解消方法 1 の代わりに解消方法 2 を用いてもほとんど同じ結果になる。しかし，4.4 節の結果から， 立体骨組の 3 次元挙動, 特にねじれを生じるような問題では, 解消 方法 1 が必要とされる場面もあると思われる。

\section{6. まとめ}

骨組の復元力特性を求めるための弾塑性増分解析は, 比較的早期 に壊れる脆性的部材が分担していた力を，骨組が平衡状態になるよ うに骨組全体の部材に再配分し，不平衡力を解消しながら進められ なければならない。しかし解析プログラムの中にはこの再配分を行 っていないものもあり，このことが復元力特性の計算結果の信頼性 を低下させている，本論文では，弾塑性大変形状態において要素の 弾性変位成分と塑性変形成分を明確に分離できる解法であれば，骨 組の現時点における弾性ひずみエネルギーの勾配として内力を評価 でき, 加えて Ramm の変位制御型荷重増分法 10)を適用することに よって, 骨組の中の脆性的な部材が早期に瞬時に壊れて復元力が不 連続に変化する場合でも, 不平衡力を解消しつつ安定に解析を進め ることができることを示した.

脆性的部材と勒性部材の混在する骨組の例として，はりが早期に 瞬時に破壊する 2 層 2 スパンの骨組を設定して，（i 破壊を無視す る，(ii）破壊を考慮するが不平衡力を解消しない，(iii)破壊を考慮し 本論文で提示した解法で解く, (iv) 破壊を考慮し不平衡力を解消し つつ, 変位制御型でない通常の荷重増分法で解く, ( v ) 破壊する部 材を当初から除く, という 5 種類の方法で数值実験的な解析を行い, 以下の結論を得た。

1. 本論文で提示した解法で解析すれば，脆性的部材が瞬時に破 壞して復元力が不連続に低下寸る場合でも，復元力特性を容易に得 ることができる，本論文で設定した数值実験骨組の場合，脆性的部 材が破壞したあとの挙動は, 破壊した部材を当初から除いた骨組と ほぼ同じ挙動になる。この傾向は文献 1 の模式図と定性的に一致し ている.

2. 不平衡力を解消しても通常の荷重増分法では復元力の不連続 な低下は検出できず，本来復元力の低下が生じる範囲では完全塑性 形になる。

3. 破壊を無視したときと破壊を考慮して不平衡力を解消しない ときの結果にはそれほど差は見られず，載荷の途中で破壊した部材 を取り除くだけで解析を進めると骨組の保有水平耐力を誤って見積 もる恐れがある。

\section{参考文献}

1) Commentary on Structural Regulations of the Building Standard Law of Japan Editorial Committee : 2015nenban Kenchikubutsu no Kouzoukankeigijutsukijunkaisetsusho (Commentary on Structural Regulations of the Building Standard Law of Japan 2015 Edition), Official Gazette Cooperation of Japan, p.344, 2015 (in Japanese) 建築物の構造関係技術基準解説書編集委員会編集：2015 年版建築物の 構造関係技術基準解説書, 全国官報販売協同組合, p.344, 2015

2) Jiang, XM, Chen, H. and Liew, JYR. : Spread-of-plasticity analysis of three-dimensional steel frames, J. Construct. Steel Res., No.58, 
pp.193-212, 2002

3) Kanao, I., Nakashima M. and Takehara, S. : Braced frame model considering buckling and fracture and its responses under near-fault strong motions, Journal of Structural and Construction Engineering (Transactions of AIJ), No.577, pp.117-122, 2004.3 (in Japanese) 金尾伊織，中島正愛，竹原創平：座屈・破断を考慮したブレース付骨組 モデルと断層近傍強震動下の応答, 日本建築学会構造系論文集, 第 577 号, pp. 117-122, 2004.3

4) Yoshimura, M. and Takaine, Y. : Evaluation of vertical deformation for $\mathrm{R} / \mathrm{C}$ columns with shear mode based on concept of failure surface contraction, Journal of Structural and Construction Engineering (Transactions of AIJ), No.592, pp.167-175, 2005.6 (in Japanese) 芳村学, 高稻宣和：破壊曲面縮小の概念に基づくせん断破壊型鉄筋コン クリート柱の鈶直変形評価に関する研究, 日本建築学会構造系論文集, 第 592 号, pp. 167-175, 2005.6

5) Hotta, H. and Yoshizaki, A. : An analytical study on collapse mechanism and seismic performance of RC frames considering the influence of shear-mode mulliontype walles, Journal of Structural and Construction Engineering (Transactions of AIJ), Vol.73, No.630, pp.1339-1346, 2008.8 (in Japanese)

堀田久人, 吉崎敦子： せん断破壊型方立て壁が $\mathrm{RC}$ 架構の崩壊形・耐震 性能に及ぼす影響に関する解析的研究, 日本建築学会構造系論文集, 第 73 巻, 第 630 号, pp. 1339-1346, 2008.8

6) Shugyo, M. : Elastoplastic large deflection analysis of three-dimensional steel frames, J. Struct. Eng., ASCE, Vol.129, No.9, pp. 12591267, 2003.9

7) Shugyo, M. and Shimazu, M. : Reduction of the total degrees of freedom in frame analysis by the Fibered Plastic Hinge Model, Journal of Structural and Construction Engineering (Transactions of AIJ), Vol.81, No.726, pp.1263-1270, 2016.8 (in Japanese) 修行稔, 島津勝： 䋊維化塑性関節モデルによる骨組解析の総自由度の低 減, 日本建築学会構造系論文集, 第 81 巻, 第 726 号, pp. 1263-1270, 2016.8

8) Freeware for 3D frame analysis FPHM \& FPHM-D, http://hdl.handle.net/10069/37150 (accessed 2018-8-28) 骨組構造解析のためのフリーウェア FPHM と FPHM-D, http://hdl.handle.net/10069/27250 (参照 2018-8-28)

9) Maeda, Y. and Hayashi, M. : Finite displacement analysis of space framed structures, J. Japan Society of Civil Engineers, JSCE, No.253, pp.13-27, 1976.9 (in Japanese)

前田幸雄, 林正: 立体骨組構造物の有限変位解析, 土木学会論文報告集, 第 253 号, pp.13-27, 1976.9

10) Ramm, E. : Riks/Wempner approach - an extension of the displacement control method in nonlinear analysis, Recent Advances in Nonlinear Computational Mechanics, Pineridge Press, pp.63-86, 1982

11) Suzuki, T., Tamamatsu, K. and Kubodera, I. : Experimental study on the elasto-plastic behavior of three dimensional frames -Studies on seismic resistivity of low steel structures, Part 2-, Transactions of the Architectural Institute of Japan, No.265, pp.33-43, 1978.3 (in Japanese)

鈴木敏郎, 玉木健一郎, 久保寺勲： 4 本柱立体骨組の弾塑性挙動に関す る実験的研究一低層鉄骨造骨組の耐震性に関寸る研究・その 2 -, 日本建 築学会論文報告集, 第 265 号, pp.33-43, 1978.3

12) Fujimoto, M. and Midorikawa, M. : Inelastic dynamic response of space frames -Part 2 Single-story, single-bay space frames with tensile bracing members-, Transactions of the Architectural Institute of Japan, No.298, pp.19-29, 1980.12 (in Japanese) 藤本盛久, 緑川光正 : 鋼構造立体骨組の動的弾塑性応答に関寸る研究一 その 2 引張筋違材を有する 1 層 1 スパン立体骨組一, 日本建築学会論文 報告集，第 298 号, pp.19-29, 1980.12

13) Shugo, M. : Elastoplastic analysis of $3 \mathrm{D}$ steel frame with tension braces by the Fibered Plastic Hinge Model, Proc. of the architectural research meetings, Kyushu Chapter, AIJ, No.56, pp.361-364, 2017.3 (in Japanese) 修行稔：繊維化塑性関節モデルによる引張りブレース付き立体鋼骨組の 弾塑性解析, 日本建築学会九州支部研究報告, 第 56 号, pp.361-364, 2017.3 


\title{
ON CANCELLATION OF UNBALANCED FORCE VECTOR IN THE ELASTOPLASTIC INCREMENTAL ANALYSIS OF A FRAME
}

\author{
Minoru SHUGYO*1 \\ ${ }^{* 1}$ Prof. Emeritus, Nagasaki University, Dr.Eng.
}

As a frame deforms under increasing external loads, relatively brittle member in the frame may fracture at an early point on the loading process. This causes sudden and considerable unbalanced force vector in the frame and then the released forces, which are axial force, bending moment, shear force and axial torsional moment of early fractured member, are redistributed into the remaining members of the frame. The elastoplastic incremental analysis to estimate the restoring force characteristics of a frame must be carried out with cancellation of above mentioned unbalanced force vector. However, it seems the dealing of those unbalanced force vector in the present most analysis codes is not necessarily clear and this reduces the reliability of the obtained values of horizontal load-carrying capacity.

In this paper a procedure to cancel a large unbalanced force vector in the elastoplastic incremental analysis of a frame is presented. The procedure is applicable only to the analysis method in which elastic and plastic components of deformations of each element can be separated explicitly from the largely deformed frame, e.g. the Fibered Plastic Hinge Method (FPHM) 6),7),8). By using the procedure, redistribution of the released forces of early fractured relatively brittle member into the remaining members of the frame can be done, therefore, an accurate restoring force characteristics of the frame having both brittle and ductile members can be obtained. The validity and reliability of the procedure are demonstrated by the analysis of two-bay two-story steel frame.

The obtained findings are as follows:

1. Using the present procedure, a discontinuous restoring force characteristics of the frame having both brittle and ductile members can be obtained.

2. A final behavior of the restoring force characteristics of the present example frame approaches to that of the frame excluded initially the fractured members. This agrees qualitatively with the schematic diagram presented in Commentary on Structural Regulations of the Building Standard Law of Japan 2015 Edition ${ }^{1}$.

3. The reliability of the horizontal load-carrying capacity of a frame obtained by the analysis without unbalanced force cancellation may not be sufficient.

(2018 年 8 月 30 日原稿受理, 2019 年 2 月 19 日採用決定) 